\title{
Functional multi-track and multilevel economic diplomacy to strengthen trade relations between Indonesia, Chile, and Peru Conditions for success
}

Fredy B.L. Tobing and Asra Virgianita

\begin{abstract}
This article analyzes the causes of low trade relations between Indonesia and Latin American states, arguing that dynamics of international political economy have opened opportunities to increase trade relations between those countries. Having good diplomatic and political relations with similar emerging economies, like Peru and Chile, should drive closer economic relations among them. A qualitative study was conducted using literature reviews, archival analysis, and in-depth interviews. Political will and lack of knowledge pertaining to the business character of each country hamper external relations. Thus, a functional multi-track diplomacy that incorporates state and non-state actors from various fields is crucial for enhancing economic relations among these countries. Trade relations can be particularly strengthened by maximizing cooperation among actors at various levels.
\end{abstract}

Keywords: Indonesia, Latin America, multilevel diplomacy, multi-track diplomacy, trade relations

Changes in international politics have yielded new perspectives regarding the relations between Indonesia and Latin American countries. The fall of the Soviet Union ushered in an era where relations among countries are based not only on deep political ties but also on growing trade figures and better economic relations. Shared values and solidarity, which had 
been the hallmark of Indonesia's relations with Latin American countries, might no longer be the driving forces in establishing deeper relations in the post-Cold War era (1990s to the present). Economic and trade relations have transformed themselves into the main catalyst in deepening and strengthening relations between countries.

The dynamic relations between countries at regional and global levels have continued to accelerate significantly since the end of the Cold War in the early 1990s. Free trade agreements (FTAs) are believed to have an impact on increasing the welfare of the countries involved in international cooperation. Free trade is also beneficial through the exchange of goods, the availability of diverse products, and technology transfer. For this reason, FTAs have been adopted by many emerging countries, such as Indonesia.

As of 2017, Indonesia has had eight FTAs, six in the region and seven at the bilateral level. At the regional level, namely the Association of Southeast Asian Nations (ASEAN) Free Trade Area (AFTA), ASEAN-Australia and New Zealand, ASEAN-China FTA, ASEAN-India, ASEAN-Japan, and ASEAN-Korea. While at the bilateral level, Indonesia has held several partnerships including the Indonesia-Japan Economic Partnership (IJEPA), Indonesia-Pakistan FTA, Indonesia-European Region, IndonesiaEuropean Union, Indonesia-Australia, Indonesia-Chile, and IndonesiaIran (Ministry of Trade of the Republic of Indonesia, 2017).

In the context of economic regionalism, for example, the Asia-Pacific Economic Cooperation (APEC) and ASEAN Economic Community (AEC) have emerged. While in the Latin American region, there is much intraregional cooperation, such as MERCOSUR and the Pacific Alliance, which is currently considering many new potential members, including Indonesia. At the same time, the discourse on the political shift from West to Rest (Zakaria, 2001) has escalated. The trend of economic growth centered in the Asia Pacific region as well as in Latin America and African countries provides the face of this shift. Countries, like Indonesia and Peru, have utilized free trade to power economic growth, further justifying the promotion of direct trade relationships between them.

Moreover, process production with abundant workforce and natural resources and a potential market are attractive within these regions. Even the World Bank report (2015) states that two-fifths of global economic growth comes from the East Asia region, so it is one of the engines of world economic growth. It is predicted that the contribution of developing countries' GDP in 2019 will reach 43.8\% (World Bank, 2015). Even foreign investment flows will continue to increase, especially in Asia and Latin America. 
Considering this situation, this study argues that developing countries such as Indonesia, Chile and Peru show a strengthening position in international trade and potential for significant trade and diplomacy among them.

The importance of the economic dimension in fostering and strengthening relations between countries has played a significant role in terms of diplomacy. Within the context of Indonesia and Latin American countries, the economic dimension has been raised through multilateral forums such as the APEC forum. APEC, which was established in 1989, aimed at increasing economic growth and relations among countries in the AsiaPacific region. The members of APEC consist of 21 countries, three of which are from Latin America (Piggott \& Woodland, 1999). The presence of Chile, Mexico, and Peru in APEC displays a strong desire to increase and strengthen interregional relations between Asia and Latin America. APEC indirectly extended an opportunity for Indonesia to increase its diplomatic relations with Latin American countries.

However, amid the rise of growing economic relations between APEC member countries, Indonesia's economic and trade relations with APEC's Latin American members have progressed slowly, aside from, perhaps, Chile, which signed a FTA with Indonesia in December 2017. This slow progress is partly due to Indonesia's diplomatic perception of the conditions of separateness. Geographical distance has been viewed by the Indonesian government and community as a major constraint in strengthening economic and trade relations (Sabaruddin \& Nugrahaningsih, 2013). However, presently Indonesia is strongly considering joining the recently enacted Comprehensive and Progressive Agreement for Trans-Pacific Partnership (СРTPP), which already includes Chile, Peru, Mexico, and some ASEAN countries (Tani, 2018).

Nevertheless, in 2011, Indonesia's trade value with Latin American countries reached US\$8.3 billion, an increase from US\$6.7 billion in 2010. However, the increase in trade volume experienced by Indonesia as compared to other Southeast Asian countries, such as Thailand, is still relatively low. In 2011, Thailand's trade volume with Latin American countries (excluding Mexico and Central American ones) reached US $\$ 8.55$ billion. In addition, Thailand signed the CPTPP FTA with Chile and Peru in 2012 and 2017 to increase their trade relations (Darmosumarto, 2012).

Indonesia faces a slightly different situation. Based on data acquired from its Ministry of Industries, in 2011, only Brazil was listed as a major export destination in Latin America for its goods, while other, considerably smaller countries in the region, such as Chile, Mexico, and Peru did not make the list (Ministry of Industry of the Republic of Indonesia, n.d). 
Contrary to the dynamics of international political economy, wherein Latin American countries are becoming major players in trade and commerce (Spillan, Virzi, \& Morales, 2017), the list also provides some insight into Indonesia's trade and economic orientation, which is still focused on traditional partners such as the United States, Japan, and Europe.

Given that background, this article analyzes why trade relations between Indonesia and Latin American countries, particularly with relation to Chile and Peru, are still underdeveloped. ${ }^{1}$ In fact, the dynamics of international political economy have opened opportunities to increase trade relations between them.

As a guiding concept, this analysis will demonstrate the use of multitrack diplomacy that incorporates not only state actors but also non-state ones from a variety of fields that are interested in increasing economic relations between countries (Diamond \& McDonald, 1996). This analysis will also focus on the use of multilevel diplomacy that has already taken place, especially as indicated by the numerous bilateral and multilateral relations that exist in the region (Bayne \& Woolcock, 2007). ${ }^{2}$ It is expected that this article will broaden views on relations between Indonesia and Latin American countries.

This research uses a qualitative approach, especially focused on secondary data analysis and in-depth interviews with resourceful persons such as ambassadors and other competent individuals in the field of diplomatic relations between Indonesia, Chile, and Peru. Accordingly, this research attempts to enhance trade relations between them, particularly in the economic diplomacy study, and provide a better understanding of the "big picture" with respect to their international political economy. It is evident that Chile and Peru are only 2 countries among the 26 in Latin America.

\section{The development of diplomatic relations between Indonesia, Chile, and Peru}

Reviewing the political spectrum, Indonesia's diplomatic relations with Chile and Peru had starting points that were different yet similar in some ways. Among Chile, Mexico, and Peru, Mexico was the first country to open diplomatic relations with Indonesia. This act was followed by Chile in 1964 and Peru in 1975. Maintaining the force of diplomatic relations for Chile, Peru, and Indonesia began with the opening of representative offices or consulates. After some time, these representative offices or consulates became embassies. 


\section{Indonesia and Chile}

With Chile, Indonesia opened its consulate in Santiago in 1964. In the meantime, for broader diplomatic affairs, Indonesia delegated oversight of Chilean affairs to the Indonesian Embassy in Argentina, located in Buenos Aires. In 1967, Chile opened its embassy in Jakarta, while Indonesia opened its embassy in Santiago 1991 (Ministry of Foreign Affairs of the Republic of Indonesia, n.d).

The Indonesian Minister of Trade noted that the trade attaché's report indicated Indonesia's engagement in 22 agreements with Chile, which contain trade promotion and trade cooperation, advancing both parties during 2007-2014. In addition, the document also recorded that 12 agreements had been ratified by Indonesia and Chile through 2013. Based on the data center website of Indonesia's Ministry of Foreign Affairs, those dozen documents consist of one set of agreed minutes, one joint declaration, six memoranda of understanding (MoUs), and four other agreements (Ministry of Foreign Affairs of the Republic of Indonesia, n.d).

Concerning these agreements, Indonesia, with respect to technical cooperation, began its special cooperation with Chile in the field of engineering through an agreement between the two governments in May 1987. At the same time, Indonesia began exploring trade cooperation with Chile through a MoU called, Trade between the Government of the Republic of Indonesia and the Government of the Republic of Chile. Five years later the two countries enhanced their trade cooperation by signing the Trade Agreement between the Government of the Republic of Indonesia and the Government of the Republic of Chile on September 2, 1982.

On August 18, 1993, the ratification of the MoU between the two governments on information cooperation reflected an expansion of the scope of their cooperation. The two countries expanded the scope of their new cooperation in the field of lighting. An agreement in the field of engineering, dated May 8, 1987, became the cornerstone of establishing a MoU between the two governments in telecommunications cooperation. Furthermore, a MoU marking the increasing scope of cooperation in the field of telecommunications was signed on June 30, 1995, in Jakarta.

On November 14, 1994, Indonesia and Chile signed the Declaration that encapsulates the idea of extending protections for and improving the environment as well as facilitating profitable investment. This came to be known as the Joint Declaration between the Government of the Republic of Indonesia and the Government of the Republic of Chile on Investments. Efforts to expand, enhance, and facilitate investment were implemented through an agreement between the two governments in the Reciprocal Promotion and Protection of Investments by adding a framework to pro- 
mote and protect foreign investment. The accord was signed on April 7, 1999.

Indonesia and Chile furthered their cooperation and an exploration of a deal in the marine and fisheries industry, through a MoU between the two governments, Marine and Fisheries Cooperation Development was drafted on March 17, 2003. On April 28, 2004, they signed an agreement on Economic and Technical Cooperation. Agreement in the field of economics and engineering was concluded by an agreement in the field of engineering, dated May 8, 1987. This partnership created a need for a joint commission through a MoU between the two governments, and this need was met by the establishment of a Joint Commission on Economic and Technical Cooperation, dated September 1, 2008. In addition, cooperation in the field of energy and mineral resources between Indonesia and Chile was run based on the Agreed Minutes between the Ministry of Energy and Mineral Resources of the two republics pertaining to energy cooperation, dated November 21, 2004.

Good relations between the two countries were also characterized by mutual visits from heads of states and high officials. For example, the president of Chile, Ricardo Lagos Escobar, visited Jakarta on April 28-29, 2004. In response, President Susilo Bambang Yudhoyono visited Santiago on November 18-21, 2004, in conjunction with the meeting of the leaders of the APEC economies that had taken place on the 12th.

Further, Indonesia and Chile also agreed on expanding the scope of cooperation in a forum. They called for a special meeting: the Bilateral Consultation Forum. This forum was realized because of the signing of a MoU between the two republics on the Establishment of Bilateral Consultations, in Santiago, on March 25, 2002. The implementation of this forum was recognized as an effort to promote bilateral relations between the two countries.

The first meeting of the forum, RI-Chile (May 2002) in Jakarta, successfully laid the groundwork for a more solid relationship and bilateral cooperation between the two countries. A similar, subsequent forum was held on May 1, 2007. In this forum, the two delegations agreed that political deliberations were conducted in a good atmosphere to further enhance bilateral cooperation more concretely, specifically covering (but not limited to) economics and engineering, maritime and fisheries, education, assessment of LNG, the establishment of a FTA, and the formation of a double tax avoidance treaty. The two countries further agreed that bilateral trade improved significantly. Trade volume between the two countries until September 2006 had reached US\$260 million and opened further opportunities for enhancing the compliance potential of each side. The forum also agreed to conduct closer cooperation in regional forums 
such as APEC and in international forums like the Forum of East AsiaLatin America Cooperation (FEALAC) and the World Trade Organization (WTO), and on international matters such as the issue of Palestine, and the Non-Proliferation Treaty (NPT). In this regard, the two delegations were appreciative of the role of each party in each region and at international forums, such as the G-15 and G-77.

Furthermore, Indonesia and Chile agreed to boost trade between the two countries via bilateral cooperation in other fields - for example, the agreement of the Bilateral Consultation Forum Indonesia-Chile, which was held on the sidelines of the ministerial-level conference of 16 in the non-aligned movement, held in Nusa Dua, Bali, on May 27, 2011. Moreover, the two countries agreed to revitalize cooperation in the fields of renewable energy, maritime and fisheries (the cultivation of seaweed in particular), air transportation, education, and diplomatic training. Specific areas of cooperation in fisheries as well as in marine and air transportation continued to be supported by both countries. The two countries also continued to explore cooperation in disaster management, sports, and interfaith dialog. Not only did the executive level engender cooperation between the two countries, but so did the legislatures. A group was formed between the parliaments of Chile and Indonesia on April 21, 2011, which encouraged the creation of friendship programs between these two parliaments.

\section{Indonesia and Peru}

A similar process occurred in connection with Peru and Indonesia. Diplomatic relations between these two countries began in 1975. At least during the early days, various activities related to the Indonesian diplomacy toward Peru were handled by the Indonesian Embassy in Brazil. Finally, on February 20, 2002, Indonesia opened its embassy in Lima. Peru's Embassy had opened in Jakarta around November 1992 (Ministry of Foreign Affairs of the Republic of Indonesia, n.d). The intensity of trade between the two countries had increased for some time after 1999, even though it slowed down because of the 2008-2009 global financial crisis.

Efforts to increase the volume of trade between Indonesia and Peru, especially to improve the value of trade, were based on international agreements made by the two countries. Among others, recorded on April 9, 2010, the ambassadors of each country signed an agreement on Economic and Technical Cooperation with the Government of the Republic of Peru. The scope of economic and technical cooperation included an exchange of information, training and specialized technical training, joint research projects in the field of science and technology, exchange between 
experts and scientists, seminars, exchanges of materials, and other forms of cooperation, all of which were agreed upon by both parties.

From the total of eight treaties, political agreements were the most prominent. Indonesia has two institutions specializing in active political relations between both countries: The Ministry of Foreign Affairs and the National Narcotics Agency. The former is the main agency of international cooperation performing the first step in strengthening the relationship between the two countries. From 2003 to 2010, the ministries of foreign affairs of the two countries made agreements concerning four items of international cooperation. Three of the four agreements were signed on February 28, 2003. The agreements focused on bilateral consultations, visa exemptions for diplomatic, official, or special passport holders, and cooperation on education and training.

This indicates that before 2013, the focus was on international cooperation, economics, and engineering. Later in 2013, the law was upheld regarding cooperation between Indonesia and Peru, and such cooperation was realized through a MoU between the National Narcotics Agency of Indonesia and the National Commission for Development and Life without Drugs of Peru, which dealt with technical cooperation regarding the Eradication of the Illicit Production, Elaboration and Commerce of Illicit Narcotic Drugs, Psychotropic Substances and Precursors. The MoU was signed in Lima on May 2, 2013.

In Bali, on October 7, 2013, the Foreign Ministry of the Republic of Indonesia and the Ministry of Foreign Affairs of the Republic of Peru signed a MoU for cooperation in the management of international agreements. The basis of this MoU was the need to cooperate in the conservation of documents and international treaties.

\section{Trade relations between Indonesia, Chile, and Peru}

Across the economic spectrum, the relationship between Indonesia and Latin American countries had shown a third occurrence of cooperative strengthening and expansion. The cooperation not only focused on the economic sphere but also ventured into politics, entertainment, tourism, and other sectors. Nevertheless, refer to Table 1, the volume of export trade between Indonesia and Mexico (over US\$200 million) ranked higher than both Chile (under US\$100 million) and Peru (under US\$40 million). Although the volume of trade between Indonesia and those countries has been volatile, its trend has been increasing (see Table 1). Meanwhile, imports from Chile occupy the highest volume from Peru (see Table 2). It peaked in 2010, and declined between 2011 and 2013. While Indonesia 
Table 1 - Indonesian exports to Chile and Peru 1999-2017 (USD)

\begin{tabular}{lrr}
\hline Year & Chile & \multicolumn{1}{c}{ Peru } \\
\hline 1999 & $73,661,753$ & $19,460,264$ \\
2000 & $84,734,701$ & $21,603,096$ \\
2001 & $85,137,796$ & $21,220,538$ \\
2002 & $65,956,329$ & $25,102,620$ \\
2003 & $67,834,123$ & $22,192,315$ \\
2004 & $90,763,552$ & $23,205,186$ \\
2005 & $113,839,153$ & $27,838,842$ \\
2006 & $152,801,121$ & $34,399,610$ \\
2007 & $135,441,913$ & $42,145,377$ \\
2008 & $128,293,032$ & $49,850,677$ \\
2009 & $166,697,871$ & $51,171,515$ \\
2010 & $192,651,824$ & $94,180,797$ \\
2011 & $175,346,547$ & $159,888,339$ \\
2012 & $213,966,915$ & $159,888,339$ \\
2013 & $170,766,832$ & $178,450,734$ \\
2014 & $177,899,071$ & $210,441,053$ \\
2015 & $147,349,521$ & $176,533,938$ \\
2016 & $143,813,166$ & $159,092,687$ \\
2017 & $158,481,229$ & $166,789,242$ \\
\hline
\end{tabular}

Source: UN Comtrade http://comtrade.un .org
Table 2 - Indonesian imports from Chile and Peru 1999-2017 (USD)

\begin{tabular}{lrc}
\hline Year & \multicolumn{1}{c}{ Chile } & Peru \\
\hline 1999 & $88,932,673$ & $26,449,254$ \\
2000 & $109,026,495$ & $41,092,934$ \\
2001 & $57,026,875$ & $45,604,922$ \\
2002 & $52,095,149$ & $27,840,149$ \\
2003 & $62,092,945$ & $19,495,548$ \\
2004 & $110,474,283$ & $25,755,719$ \\
2005 & $135,611,838$ & $36,442,210$ \\
2006 & $197,945,155$ & $31,175,268$ \\
2007 & $202,631,760$ & $27,971,510$ \\
2008 & $274,273,676$ & $36,180,569$ \\
2009 & $189,212,024$ & $36,472,281$ \\
2010 & $309,054,738$ & $31,457,237$ \\
2011 & $372,261,526$ & $51,388,623$ \\
2012 & $206,640,932$ & $72,678,999$ \\
2013 & $241,248,160$ & $51,801,152$ \\
2014 & $241,506,407$ & $66,786,467$ \\
2015 & $173,847,935$ & $52,723,286$ \\
2016 & $83,339,009$ & $59,302,713$ \\
2017 & $120,019,442$ & $63,016,214$ \\
\hline
\end{tabular}

Source: UN Comtrade http://comtrade.un .org

imports from Peru underwent fluctuations, from 1999 to 2002 Peru occupied second place after Chile. Regarding total trade, Indonesia's total trade with Chile reached US\$546,608,073 and US\$277,227,520 with Peru (Table 3). This indicates that the volume of trade between Indonesia and Chile is bigger than it is with Peru. The balance of trade data was based on the value of Indonesia's imports from Chile, resulting in a trade deficit for Indonesia, except in 2001, 2002, 2012, 2015, 2016 and 2017. Similarly, with Peru, Indonesia has had a trade deficit from 1999 to 2002. However, after changing to a trade surplus in 2003, this situation changed and remains constant (Graph 1).

Based on data provided by the WTO, Latin America has shown an average growth rate of $1.5 \%$ to $6 \%$ (World Trade Organization, n.d.). The WTO has also listed Chile and Peru among countries with the potential of becoming emerging economies in Latin America. Indonesia's past focus 
Table 3 - Indonesian trade value with Chile and Peru 1999-2014 (USD)

\begin{tabular}{|c|c|c|c|c|c|}
\hline Year & Chile & Peru & Year & Chile & Peru \\
\hline 1999 & $162,594,426$ & $45,909,518$ & 2009 & $355,909,895$ & $87,643,034$ \\
\hline 2000 & $193,761,196$ & $62,696,030$ & 2010 & $501,706,562$ & $125,638,034$ \\
\hline 2001 & $142,164,671$ & $66,825,460$ & 2011 & $546,608,073$ & $211,276,962$ \\
\hline 2002 & $118,051,478$ & $52,942,769$ & 2012 & $420,607,847$ & $232,567,338$ \\
\hline 2003 & $129,927,068$ & $41,687,863$ & 2013 & $412,014,992$ & $230,251,886$ \\
\hline 2004 & $201,237,835$ & $48,960,905$ & 2014 & $419,405,478$ & $277,227,520$ \\
\hline 2005 & $249,450,991$ & $64,281,052$ & 2015 & $321,197,456$ & $229,257,224$ \\
\hline 2006 & $350,746,276$ & $65,574,878$ & 2016 & $227,152,175$ & $218,395,400$ \\
\hline 2007 & $338,073,673$ & $70,116,887$ & 2017 & $278,500,671$ & $229,805,456$ \\
\hline 2008 & $402,556,708$ & $86,031,246$ & .org & & comtrade.un \\
\hline
\end{tabular}

on Brazil as its only trading partner in Latin America suggests that Indonesia's economic diplomacy toward APEC members from Latin America has been insufficiently explored.

From the perspective of Chile and Peru, trade relations with APEC members have increased due to growth in the Asian economies at the expense a slow growth of Europe and the United States. Based on estimates from WTO, China is the new leading economy, positioning itself as a stra-

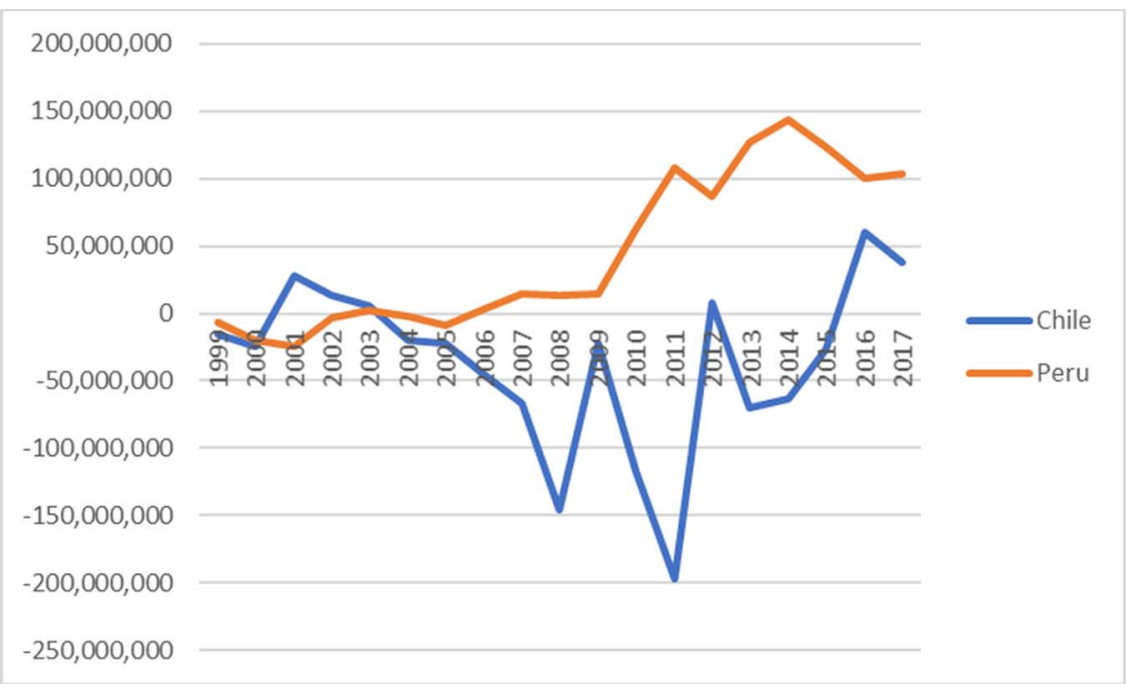

Graph 1 - Balance of trade between Indonesia, Chile, and Peru (USD) 1999-2017

Source: UN Comtrade 
tegic trade ally for Latin American countries. China's position as a strategic economic partner to Latin American countries has ranked it within the top five export destination countries in the region. The other Asian APEC member country that is ranked fourth among the top five export destinations for Latin America is Japan (World Trade Organization, n.d). Indonesia, in contrast, has not yet demonstrated itself as a strategic economic partner with Latin American countries, especially Chile and Peru, within the APEC framework.

The trade volume between Indonesia and Chile in 2013 was US\$156.4 million, US $\$ 23.2$ million less (-12.9\%) than in 2012 (US\$179.7 million). Chile imported US\$67.9 million from Indonesia during the same period, a decrease of US\$17.1 million (-20.1\%) as compared to 2012. Chilean exports to Indonesia in 2013 also decreased to US $\$ 88.5$ million, a decline of US\$6.1 million $(-6.5 \%)$, as compared to US\$94.6 million in 2012. Indonesia's trade deficit with Chile reached US\$20.6 million in 2013 (Ministry of Trade of the Republic of Indonesia, 2013).

Regarding trade with Peru, the total trade volume in 2012 reached US $\$ 232.5$ million, increasing by $33.36 \%$ that year. Indonesian exports to Peru, though still relatively modest, were valued around US $\$ 159.8$ million, which were generated from motorcycles, refrigerators, DVD players, paper products, and shoes (Tempo.co, 2013).

\section{Challenges and barriers}

The causes for low trading volumes with other countries include: the distance from Indonesia, bureaucracy, and the understanding of each country's respective trade character. Geography may indeed inhibit trade in many ways, but considering the substantial trade between most Latin American countries and Indonesia's neighboring countries (i.e., Malaysia, the Philippines, and Thailand), such barriers do not provide a strong explanation of low trade volume between Indonesia, Chile, and Peru. On the contrary, this study suggests that the main culprit is the political will of the governments. In addition, Indonesia's orientation to traditional partners is still strong, naturally affecting the perspective and political will of the country and working against the need to build relationships with non-traditional partners.

Indeed, the non-material barriers that block off communities from engaging in trade has resulted in a lack of interaction and relationship building between Indonesia, Chile, and Peru, even though they have had a good relationship for quite a while. These obstacles may be noted by observing the orientation of business and travel from those countries. A 
growing business orientation is still inward looking, such as an orientation based on the understanding that the results of domestic production are intended to meet the needs of the domestic market in advance as well as an understanding that the domestic market has not yet reached a saturation point. From travel evidence, if people from Peru travel to Asia, they go to Hong Kong or Japan, even though Indonesia is a five-hour flight from those two countries. Similarly, the Indonesian community tends to travel to the United States, but upon arriving in America does not take a trip to Peru, which is only five hours away.

Bureaucratic obstacles mainly relate to the permitting process - a convoluted procedure influencing trade and import-export product distribution in Indonesia. The sluggish bureaucratic processes at the port, for example, have an impact on the length of a country's product distribution to the consumers in Indonesia. It is judged detrimental, especially when fruit is the commodity Chile exports to Indonesia because long transportation times reduce the commodity's quality. Thus, bureaucratic efficiency of export-import in Indonesia, particularly in the major ports, must be improved.

One of the other challenges is the unavailability of complete data about business opportunities and partners in Chile and Peru. Better data availability could assist a country's understanding of the character of its trading partner. For example, the character of trade relations in Chile is business-to-business (B2B). The government of Chile rarely intervenes in its formulation and implementation (H.E. Ibrahim Ambong, personal communication, September 5, 2014). Having a character of trade that focuses on B2B trade agreements speeds up the process and makes it more dynamic and in line with the market demand for the two countries. Indonesia's scheme requires extensive improvement and enhancement if it has to match Chile's.

Nevertheless, this study's result suggests that some support from the government must exist in B2B schemes. The government should participate in the scheme without beleaguering it with convoluted bureaucracy, inefficiency, and ineffectiveness. This goal is important considering that the function and purpose of business groups and the government differ. Businesses will always be oriented to benefiting themselves as fully as possible, without necessarily thinking about the interests of the community, while government must ensure that all activities and relations, including trade relations with foreign countries, must take precedence to national interests, which also brings benefits to the Indonesian society as a whole. This relates to the scheme offered by Susan Strange (1992), who puts two patterns of relationship collaboration between the government and business groups - for instance, partnerships and alliances. 
Regarding regional cooperation, Chile and Peru have established the Pacific Alliance with Colombia, and both are members of the CPTPP. The results of interviews with representatives suggest that in Chile and Peru, the promotion of a Pacific Alliance is one of the gateways that can be used by countries for trading their products through a liaison (hub). The purpose of the formation of any Pacific Alliance is to increase and improve the quality of human resources within a region (H.E. Roberto Hernan Portocarreo, personal communication, October 7, 2014).

\section{Functional multi-track and multilevel economic diplomacy}

Based on the aforementioned facts and ideas, trade relations between Indonesia, Chile, and Peru are weakened because there is still no strong political will by the government of Indonesia or its counterparts to further increase trade relations. An orientation toward traditional partners still dominates the mindset of each country. In addition, the distance factor does not contribute much to the problem of trade itself but rather highlights the need to establish connectivity between the communities (people-to-people) including breaking down of non-material barriers in each community. This certainly affects the inadequate utilization of multi-track diplomacy with respect to Indonesia, Chile, and Peru. Understanding the character of trade in each country is also weak, leaving a better understanding of opportunities in each country dormant. Moreover, the bureaucratic system is weak, opaque, and convoluted, which thus appears to be one of the major constraints impeding countries from having stronger trade with Indonesia.

\section{Multi-track diplomacy: Strengthening relations from the bottom up}

Considering the bilateral relations between Indonesia, Chile, and Peru, the majority of past relationships were conducted on a government-togovernment (G2G) level, whereas the implementation of agreements was mostly carried out by state ministries. However, over the last two decades, and due to a shift in global perception among governments to include non-state actors such as firms, civil society as well as individuals, in developing closer bilateral and multilateral relations between states, the number of interactions between non-state actors with respect to these countries has increased.

In the 1990s, relations between Indonesia and Chile were conducted by non-state actors, having increased mainly through people-to-people interactions in tourism and civil society dialogues (e.g., interfaith dialogues) 
(Ministry of Foreign Affairs of the Republic of Indonesia, n.d.). Doing so has brought together religious leaders from both countries to discuss social issues and exchange insights on lessons learned. Firms from both sides of the Pacific have also shown interest in conducting investments and trade between the two countries. Presently, there are at least three Chilean firms investing in Indonesia: Comerciolizadora Jarza, Devet Solutions, and Fexa International (Ministry of Foreign Affairs of the Republic of Indonesia, n.d.). One of Indonesia's largest agribusiness firms, PT Smart Tbk, is investing in Chile through Crude Petroleum Oil (CPO trade.

With Peru, even though Indonesia has no significant developments in terms of trade and investment, agreements signed by both countries for agricultural cooperation have provided the opportunity to increase the dialogue of researchers and offers of technical assistance in developing agricultural and farming technologies.

This study also contends that non-state actors' diplomacy has several advantages. First, non-state actors have the flexibility to undertake work and cooperation, in both methodology and mobility. Second, different from state actors working with formal methods, non-state actors may work both formally and informally. Third, non-state actors play a role in the soft power area. Therefore, they minimize tendencies of political interests in countries that might affect them. Considering the advantages of non-state actors, it is crucial to strengthen trade relations between Indonesia, Chile, and Peru by means of first- and second-track diplomacy functions of government and non-state actors, respectively.

\section{Multilevel economic diplomacy: Mixing bilateral, regional, and multilateral approaches}

Trade relations between Indonesia, Chile, and Peru can be maximized through an increasingly diverse and complex network of intersection in cooperation, where trade cooperation is bilateral, regional, and positively multilateral. Development of cooperation through intersection provides explanation and justification that suggest that distance is no longer an obstacle to a country's cooperative trade efforts. Nevertheless, the complexity of these negative ideas has given rise to an unfortunate phenomenon known as the "spaghetti bowl."

Furthermore, Indonesia, Chile, and Peru already participate with international trade organizations, such as the WTO, APEC, and FEALAC. The latter two may be utilized to strengthen and expand cooperation among those countries. However, for FEALAC, considering that this forum was established in order to build closer relations between East Asia and Latin America, special intensive communication could be formally 
and continuously conducted. In the meantime, non-economic organizational memberships, the involvement of Chile and Peru in the non-aligned movement (NAM), for instance, should provide stronger bonding with economic justification between these two countries and Indonesia (as one of the founders of NAM). In addition, Indonesia, Chile, and Peru can also utilize South-South cooperation to increase their relations in both economic and political aspects.

In terms of regional integration, Chile and Peru are affiliated with several regional economic integration organizations. Peru recently joined with some of the other strongest economies (Chile, Colombia, and Mexico) in the region to form a new organization, the Pacific Alliance. It also joined the CPTPP. Besides aiming to promote regional economic integration through garnering more trade within the region, the Pacific Alliance also aims to strengthen and coordinate the group's economic ties with Asia, just like the CPTPP has done. A year after forming the alliance, the members agreed to its rules of operation on May 23, 2013, making it the largest free trade zone in Latin America. All the four countries have open market economies, embrace globalization, average $5 \%$ economic growth rates, and constitute $35 \%$ of Latin America's gross domestic product (UNASUR, n.d).

The establishment of the Pacific Alliance and the participation of Mexico, Chile, and Peru in various international organizations have displayed the potential of increasing the relationship with Indonesia and the possibility of doing it profitably through a variety of organizations. Even thirdparty countries have been extensively promoting the Pacific Alliance as the gateway and hub for any country to market its products in Latin America. They also promote the Pacific Alliance, as regional cooperation can help countries that have difficulties in pioneering trade relations. By comparison, like trading partners in the Asia-Pacific region, it is becoming increasing clear that Latin America has emerged as a key trading partner for Asia. The same situation also applies to Latin America. Although still dominantly tied to the United States and European countries, developments in recent years have indicated a growing interdependence with Asia.

On a global level, Chile and Peru have been integrating into the world economy, signing FTAs with the United States and other key trade partners, such as Canada, China, Japan, Singapore, South Korea, and Thailand. Chile and Peru joined the APEC in 1998, which promotes economic relations between Latin American and Asian countries. Peru is an active member and hosted the APEC summit in 2008. Evidently, the biggest advance happened in 2017, when the CРTPP went into force.

Concerning the participation in regional and multilateral organizations, Indonesia is one of the most active countries in the ASEAN. In- 
donesia is the only ASEAN country that is a member of the G20. In addition, Indonesia is also an active member of the APEC forum, as are Chile and Peru. Consequently, relations between Indonesia, Chile, and Peru should become even closer than before, especially in terms of economic activities.

\section{Conclusion}

Given the commonalities in both diplomatic and economic spectrums, the implementation of multi-track economic diplomacy through the incorporation of non-state actors, such as firms, civil society groups as well as individuals could complement state efforts to increase trade volumes and economic cooperation between Indonesia, Chile, and Peru. In addition, it could be an alternative means to intensify relations that are difficult to conduct through government. In terms of multilevel economic diplomacy, since most of the countries within the region have established bilateral agreements and are engaged in numerous multilateral forums, fostering interregional relations between regional forums would serve as an umbrella not only to increase G2G relations but also to foment interregional business forums, civil society activities, and individuals alike.

With regard to the status of being an emerging economy, one which is shared by Indonesia and Peru - and to a lesser extent Chile-such a push would doubtlessly bring together other countries and promote regional cooperation. Such a drive would also affect other, broader fields, such as technology, education, and a cultural exchange element that would serve to increase people-to-people interactions.

On December 14, 2017, Indonesia and Chile finally signed the Indonesia-Chile Exchanged Comprehensive Partnership Agreement (IC-CEPA), which initiated in 2006 (Ministry of Trade of the Republic of Indonesia, 2017). Thus, on June 11, 2019, the agreement is entering an exchange of Instrument of Ratification (IoR) process. IC-CEPA is the first and only Indonesian agreement with Latin America countries (Ministry of Foreign Affairs of the Republic of Indonesia, 2019). In 2018, Indonesia and Chile also expanded its relation by signing a MoU on Fisheries and Agriculture in Bali (Ministry of Foreign Affairs of the Republic of Indonesia, n.d.). Meanwhile, in the same year, Foreign Minister of Indonesia and Foreign Minister of Peru agreed to initiate comprehensive trade cooperation by signing the Trade in Goods Agreement (TIGA) as the first milestone (Ministry of Trade of the Republic of Indonesia, 2018). On April 3, 2019, the Indonesian Embassy in Lima, Peru, in collaboration with Camara de Comercio Lima (CCL) has organized the Indonesian Market Update, which is an event 
designed to promote trade and tourism (Ministry of Trade of the Republic of Indonesia, 2019). This event was attended by business groups from both countries. These activities confirm the idea of this article to function multitrack and multilevel diplomacy. Through this process, non-material barriers are expected to be eliminated in the foreseeable future, considering it is one of the major constraints in stifling the growth of trade relations among countries.

FREDY B. L. TOBING is a doctor of political science, former head of International Relations Department and executive director of the Center for International Relations Studies (CIReS) the Faculty of Social and Political Sciences, Universitas Indonesia. Mr. Tobing has a keen interest on regional economic issues. His publications include "Kerjasama Ekonomi Asia Timur: Telaah Terhadap Prospek Hubungan ASEAN-India [Economic cooperation in East Asia: a study on the prospects of ASEAN-China relations]" (2009), "Praktik Relasi Kekuasaan Soeharto dan Krisis Ekonomi 1997-1998 [The pratice of Suharto's power relations and economic crisis in 1997-1998]" (2014), "Beyond ASEAN economic community: Meninjau Hubungan Perdagangan ASEAN dan Amerika Latin sebagai Mitra Baru [Beyond ASEAN economic community: Analysis trade relations between ASEAN and Latin America as a new partner]" (2015), "Diplomasi Ekonomi dalam Kerja Sama Selatan-Selatan: Studi Komparatif antara Malaysia dan Indonesia [Economic diplomacy in south-south cooperation: A comparative study between Malaysia and Indonesia]" (2016), and "Fenomena Negara Islam di Iraq dan Suriah (NIIS): Telaah Hubungan Internasional [The phenomenon of Islamic State in Iraq and Syria: International relations perspectives]" (2017). Email: fredyblt@ui.ac.id

ASRA VIRGIANITA is a doctor of international studies and head of the Post-Graduate Program, International Relations, Universitas Indonesia. Mrs. Virgianita has written many publications on foreign aid, ASEAN, trade cooperation and international development, such as "Japan's democracy assistance in Indonesia: A comparison with the United States and the EU" (2011), "Perkembangan Diskursus dan Implementasi Bantuan Luar Negeri dalam Studi Hubungan Internasional [Discourse and the implementation of foreign aid in international relations study] " (2014), Liberalisasi Jasa ASSEAN dan Tenaga Kerja Terampil [Indonesia Liberalization of services in ASEAN and skill labours in Indonesia], "Otoritas Jasa Keuangan \& Konglomerasi Keuangan: Tinjauan Ekonomi-Politik [Financial supervisory agency and financial sector conglomerate]" (2015), "Beyond ASEAN Economic Community: Meninjau Hubungan Perdagangan ASEAN dan Amerika Latin sebagai Mitra Baru [Beyond ASEAN economic community: Analysis trade relations between ASEAN and Latin America as a new partner] (Co Authors)" (2015), "Indonesia's subnational competitiveness and preparedness for ASEAN economic community 2015: Mapping literatures" (2018), and "Donors, government and society in Indonesia's democratic elections" (2018). Her current research is related to South-South cooperation. Email: asrahiui@ui.ac.id 


\section{NOTES}

1. Considering that Mexico has increased its trade relations with Indonesia in recent years, the article is focused only on Chile and Peru as members of the APEC forum

2. For details about multi-track diplomacy see Diamond \& McDonald, 1996, pp. 1-2. For details about multilevel diplomacy, see Bayne \&Stephen Woolcock, 2007, chapters 1, 9-10.

\section{REFERENCES}

Bayne, N., \& Woolcock, S. (2007). The new diplomacy: Decision-making and negotiation in international economic relations. Aldershot: Ashgate Publishing Company.

Darmosumarto, S. (2012, June 20). Indonesia's outreach to Latin America. Retrieved from http://www.thejakartapost.com/news/2012/06/20/indonesia-s-outre ach-latin-america.html

Diamond, L., \& McDonald, J. (1996). Multi-track diplomacy: A system to peace. West Hardford: Kumarian Press.

Ministry of Foreign Affairs of the Republic of Indonesia. (n.d.). Daftar Perjanjian Internasional Chile. Retrieved from http://www.kemlu.go.id/Daftar\%20Perjan jian\%20Internasional/chile.htm

Ministry of Foreign Affairs of the Republic of Indonesia. (n.d). International treaty research. Retrieved from https://treaty.kemlu.go.id/search

Ministry of Foreign Affairs of the Republic of Indonesia. (n.d.). KBRI Peru. Retrieved from http://www.kemlu.go.id/santiago/Pages/Divisions.aspx/IDP=1 \&l=ide

Ministry of Foreign Affairs of the Republic of Indonesia. (n.d.). List of international agreement. Retrieved from http://treaty.kemlu.go.id/index.php/treaty/ index?fullPage $=1 \&$ Treaty\%5Bcountry_id $\% 5 \mathrm{D}=32 \&$ Treaty\%5Bwork_field_ id $\% 5 \mathrm{D}=55 \&$ Treaty $\% 5$ Bwork_type_id $\% 5 \mathrm{D}=1 \&$ Treaty $\% 5 B$ keywords $\% 5 \mathrm{D}=$ con sultations

Ministry of Foreign Affairs of the Republic of Indonesia. (2019). Indonesian Market Update, Upaya Jaring Kerjasama Bisnis Indonesia-Peru. Retrieved from https://kemlu.go.id/lima/id/ext-news/192/indonesian-market-update-upayajaring-kerjasama-bisnis-indonesia-peru

Ministry of Industry of the Republic of Indonesia. (n.d.). Major export destinations. Retrieved from http://www.kemenperin.go.id/statistik/negara.php?ekspor

Ministry of Trade of the Republic of Indonesia. (2013, October 17). Developments in Indonesian-Chilean Trade Relations. Retrieved from http://www.kemendag .go.id/files/pdf/2013/10/17/report-1382005932.pdf

Ministry of Trade of the Republic of Indonesia. (2017). Factsheet: Indonesia-Chile Comprehensive Economic Partnership Agreement. Retrieved from http://ditje nppi.kemendag.go.id/assets/files/publikasi/doc_20180523_fact-sheet-indone sia-chile-cepa.pdf 
Ministry of Trade of the Republic of Indonesia. (2018). Indonesia Trade Negotiations as of May 2018. Retrieved from http://ditjenppi.kemendag.go.id/assets/files/ publikasi/doc_20180511_on going-and upcoming-negotiations4.pdf

Ministry of Trade of the Republic of Indonesia. (2019). Pertukaran IOR Indonesia-Chile CEPA: Selangkah Lagi Perjanjian Dagang Indonesia-Chile Mulai Berlaku. Retrieved from https://www.kemendag.go.id/files/pdf/2019/06/11/pertuka ran-ior-indonesia-chile-cepa-selangkah-lagi-perjanjian-dagang-indonesiachile-mulai-berlaku-id0-1560234085.pdf

Piggott, J., \& Woodland, A. (1999). International trade policy and the Pacific Rim. London, UK: Macmillan Press LTD.

Sabaruddin, S. S., \& Nugrahaningsih, H. (2013). Assessing Indonesia-Chile bilateral trade opportunities: A revealed comparative advantage approach. Economic Journal of Emerging Markets 15(1), 45-56.

Spillan, J., Virzi, N., \& Morales, M. A. (2017). Business opportunities in the Pacific: The economic rise of Chile, Peru, Colombia, and Mexico. Cham, Switzerland: Palgrave Macmillan.

Strange,Susan. (1992). States, firms and diplomacy. International Affairs 68 (1), 1-15.

Tani, S. (2018, June 12). Indonesia making preparations to join TPP. Retrieved from https://asia.nikkei.com/Spotlight/The-Future-of-Asia-2018/Indonesia-mak ing-preparations-to-join-TPP

Tempo.co. (2013, September 6). Indonesia Ingin Genjot Ekspor ke Brasil dan Peru. Retrieved from https://bisnis.tempo.co/read/510939/indonesia-ingin-genjotekspor-ke-brasil-dan-peru/full\&view $=$ ok

UNASUR. (n.d.). Retrieved from http://www.comunidadandina.org/sudamerica .html

UN Comtrade Database. (n.d). Download trade data. Retrieved from https://com trade.un.org/data/

World Bank. World Bank Annual Report 2015. Retrieved from https://www.world bank.org/en/about/annual-report-2015

World Trade Organization. (n.d.). Trade profiles. Retrieved from http://stat.wto.org/ CountryProfile/WSDBCountryPFView.aspx?Language=E\&Country=CL

Zakaria, Fareed. 2001. Post American world and the rise of the rest. London, UK: Penguin Press.

\section{INTERVIEWS}

Ambassador of Peru to Indonesia, H.E. Roberto Hernan Portocarreo. 2014. Interview with authors. 7 October.

Indonesian Ambassador for Chile (2006-2010), H.E. Ibrahim Ambong. 2014. Interview with authors. 5 September. 


\title{
Diplomacia económica en las relaciones comerciales entre Indonesia, Chile y Perú
}

\author{
Fredy B.L. Tobing, Asra Virgianita
}

Resumen: Este artículo analiza las débiles relaciones comerciales entre Indonesia y América Latina, argumentando que la dinámica de la economía política abre oportunidades para mejorar estas relaciones. Las buenas relaciones diplomáticas y políticas entre Perú y Chile, debería estrechar sus relaciones económicas. Pero la escasa voluntad política y falta de conocimiento del carácter empresarial de cada país, obstaculizan sus relaciones externas. La investigación incluyó revisión de literatura, análisis de archivos y entrevistas en profundidad. Los resultados subrayan la necesidad de una diplomacia funcional de múltiples rutas que incorpore instituciones estatales y no estatales de diversos campos para mejorar las relaciones económicas. Las relaciones comerciales particularmente pueden fortalecerse entre países maximizando su recíproca cooperación en cada nivel (diplomacia multinivel).

Palabras clave: América Latina, diplomacia multinivel, Indonesia, múltiples rutas diplomáticas, relaciones comerciales

\section{Une diplomatie économique fonctionnelle et multiple pour renforcer les relations commerciales entre l'Indonésie, le Chili et le Pérou}

\section{Fredy B.L. Tobing, Asra Virgianita}

Resumé : Cet article analyse les causes de la faiblesse des relations commerciales entre l'Indonésie et les pays d'Amérique latine en faisant valoir que la dynamique de l'économie politique internationale a ouvert des opportunités pour stimuler les relations commerciales entre ces pays. Cette étude qualitative a été menée sur la base d'une étude de la littérature existante, d'analyses archivistiques et d'entretiens approfondis. Le manque de volonté politique et surtout de connaissances réciproques des atouts commerciaux de ces pays entravent leurs relations extérieures. Ainsi, une diplomatie fonctionnelle à plusieurs voies qui intègre des diplomaties étatiques et non-étatiques dans divers domaines est-elle cruciale pour améliorer leurs relations économiques. Les relations commerciales peuvent notamment être renforcées en maximisant la coopération entre ces pays à chaque niveau (diplomatie multi-niveaux).

Les mots-clés : Amérique latine, diplomatie à plusieurs voies, diplomatie multi-niveaux, Indonésie, relations commerciales. 